\title{
Online Medical Education during Covid-19 Pandemic in Bangladesh: Problems and Prospects
}

\author{
Shakila Parvin* \\ Assistant Professor of Pharmacology, Kushtia Medical College, Bangladesh
}

*Corresponding author: Dr. Mst. Shakila Parvin, Assistant Professor of Pharmacology, Kushtia Medical College, Kushtia-7200, Bangladesh, Email: parvinshakila29@gmail.com

\section{Research Article \\ Volume 5 Issue 1}

Received Date: December 26, 2020

Published Date: January 06, 2021

DOI: $10.23880 /$ eij-16000174

\section{Abstract}

The education system has been lockdown during the COVID-19 pandemic globally for primary to higher education and Bangladesh is not out of this. Finding no other alternative, online education system has been introduced by internet-based video classes like zoom, Facebook, Google class, and many others like these. Though medical education is very important and mainly based on classroom, lab tests, and hospital but during this pandemic, due to lockdown it has been continuing by the online system. Kushtia Medical College has started online classes via zoom since July 2020. It has its own ID and password. However, a number of benefits, problems, and few prospects have been found in this study. The crucial finding of this study is online classes is not fruitful for a long time as medical education is highly technical, professional, and specialized and based on a practical, lab test, and patients tests. However, for a temporary period, it is moderately helpful for students. If prolong pandemic stay, medical education including all kinds of education will hamper and session jams will appear throughout the world which would be harmful to the global education, economy, governance, health, safety, and peaceful world.

Keywords: Online Education; Internet; Medical Education; Bangladesh

\section{Abbreviations: MOOCs: Massive Open Online Courses}

\section{Introduction}

COVID-19 pandemic has locked the education systems globally affecting nearly 1.6 billion learners in more than 200 countries of the world [1]. The sudden closure of educational institutions has impacted 94 percent of the world's student population, up to 99 percent in low and lower-middle-income countries [2]. Online education is an educational system where information technologies and communications are used for the acquisition of knowledge from remote locations $[1,3]$. It uses internet and video, audio, text communications as well as software to create the learning environment. The synonyms of online classes are virtual class, e-learning, distance learning, etc. The online classroom replaces the traditional classroom of blackboard, whiteboard, projectors of an educational institute with a virtual environment [4].
Moving smoothly from an environment of conventional education to a virtual platform could not happen overnight. However, the massive efforts made by many institutions in a short time proved that change is possible [5-8].

The government of Bangladesh closed all in campus educational activities due to the COVID-19 pandemic since $18^{\text {th }}$ of March 2020 and that clicked a sudden pause of teaching-learning activities [2]. As like in other countries, the online class has introduced a major focus in the education system of Bangladesh. However, virtual teaching had been a new experience in almost all medical colleges; sudden closures of face-to-class gave the least opportunity to both the faculty and students to get adopted with the new option of virtual class and classroom. The current paper presents the results of a web-based survey exploring their own views of MBBS students of Kushtia Medical College regarding the online classes attended by them. Perspectives of students may 


\section{Epidemiology International Journal}

also bring out recommendations for further development in this field for the same study site.

\section{Background and Existing Literature}

The study is an attempt to address the reality of medical education during the COVID-19 pandemic in Bangladesh. Bangladesh is one of the most densely populated countries in the world with nearly 160 million people within an area of 147,570 square kilometers. Its vast population would be the major resource of the country [9]. However, transforming the potential people into a productive force and ensuring a dynamic environment for social, economic, and political development is still a big challenge for its government. Though the literacy rate is officially said to be $66 \%$, according to a private survey the rate is only $42 \%$. Education, therefore, has been recognized as a priority sector by all governments since its independence in 1971 [9]. Today, digital information is everywhere and available to almost everyone. In this era of information technology, medical education is now confronted with novel challenges. On the one hand, the online healthcare information boom is continually challenging medical students to rapidly update and expand their existing body of knowledge. On the other hand, the informatics competency requirements of healthcare technology, such as utilizing electronic healthcare records, learning systems, and aideddiagnosis systems, also present a new challenge for medical students to master [10], even for the so-called digital native learners [11].

To prepare qualified doctors for today's environment in which the internet provides ubiquitous digital information, the teaching methods used for educating and training medical school students should be reconsidered [9]. Offline learning, or traditional classroom teaching, represents teaching in the pre-internet era. Although some forms of information technology have already been utilized to assist instruction, traditional teaching methods required that teaching and learning should take place at the same time and place [9]. Online learning, also called internet-based learning or webbased learning, does not have the time and space limitations, and therefore, makes teaching and learning separable via internet-based information delivery systems. Both online and offline teaching has been widely used in higher education. The use of online learning has vastly increased since 2012, as evidenced by the thriving of massive open online courses (MOOCs) [12].

However, evaluating the effectiveness of online and offline teaching remains difficult. Evaluations have failed to reach consistent conclusions $[13,14]$, resulting in complex decisions when selecting a teaching method for medical education. The effectiveness of online learning is influenced by many factors. Some factors create barriers for online learning, such as administrative issues, social interaction, academic skills, technical skills, learner motivation, time and support for studies, technical problems, cost, and access to the internet [15]. Other factors could result in low-quality online learning, for example, an ineffective design and arrangement of multimedia materials [16]. The effective analysis of online and offline teaching in medical education, therefore, should depend on a comprehensive consideration of how they are used across groups. It should all be assessed including the learning goals, design properties of the learning materials, evaluation of learning outcomes, etc. This paper focused on online medical education during the COVID-19 pandemic crisis in Bangladesh.

\section{Materials and Methods}

It is a qualitative case study focused on Bangladesh based on both primary and secondary data. It is a questionnairebased observational study conducted on MBBS students of Kushtia Medical College. The study period was from August to October 2020 at Kushtia Medical College. The classes were conducted by zoom video which capable to count attendance involuntary. Therefore, class percentage (\%) of attendance has been counted easily. The questionnaire was both close and open-ended. The answer options were yes/no, and then why yes or no? 51 students were included purposively as respondents who were attended online classes by zoom. Besides, I was involved directly with them as a course teacher. Therefore, I have observed them closely and realize their problems and opportunities as an observer and host. The secondary data were collected from review of literature like published journal articles, newspaper reports, and online publications through internet browsing.

\section{Data Presentation and Analysis}

There are several methods and techniques in the presentation of data for qualitative research. In this study, collected data have been presented by using a single table only. Similarly, numerous scholars mentioned various methods and tools for qualitative data analysis. However, three main techniques have been found common for qualitative data analysis, Thematic Analysis, Content Analysis, and Narrative Analysis. In this study, the narrative discussion has been conducted as this method is used to analyze content from various sources, such as interviews of respondents, surveys, or observations from the field. Table 1 represents the collected data from the respondents. 


\begin{tabular}{|c|c|c|c|c|}
\hline \multirow{3}{*}{ Questions } & \multicolumn{4}{|c|}{$\begin{array}{c}\text { Types of Response } \\
\text { (Total respondents 51) } \\
\end{array}$} \\
\hline & \multicolumn{2}{|r|}{ Yes } & \multicolumn{2}{|r|}{ No } \\
\hline & (\%) & $\begin{array}{l}\text { Remarks } \\
\text { Why yes? }\end{array}$ & (\%) & $\begin{array}{l}\text { Remarks } \\
\text { Why yes? }\end{array}$ \\
\hline $\begin{array}{l}\text { 1. Do you find any } \\
\text { benefits of online } \\
\text { education? }\end{array}$ & $20(39 \%)$ & $\begin{array}{l}\text { 1. Easy to attend without class room; } \\
\text { 2.Social distance maintain is possible; } \\
\text { 3. Theoretical class has completed; } \\
\text { 4.Online medical education is keeping us } \\
\text { busy as a result we are not affected by } \\
\text { depression; } \\
\text { 5. Online classes are always better than } \\
\text { no classes at all. At least we are getting } \\
\text { some basic ideas and guidelines about } \\
\text { our courses. }\end{array}$ & $31(61 \%)$ & $\begin{array}{l}\text { 1. Listening problem } \\
\text { 2.Practical, lab and ward } \\
\text { visit is not possible } \\
\text { 3. Difficult to interact due to } \\
\text { poor internet speed. } \\
\text { 4. Real learning is } \\
\text { impossible. } \\
\text { 5. Absenteeism is high due } \\
\text { to lack of ICT devices and } \\
\text { lack of internet access }\end{array}$ \\
\hline $\begin{array}{l}\text { 2.Do you face any } \\
\text { problems in online } \\
\text { education? }\end{array}$ & $47(92 \%)$ & $\begin{array}{l}\text { 1. Lack of schedule for regular class; } \\
\text { 2.Interruption of internet due to lack of } \\
\text { and poor broad band internet; } \\
\text { 3. Unavailable of internet in rural areas; } \\
\text { 4. Lack of electronic devices (Laptop, } \\
\text { computer, and Smart Phone). } \\
\text { 5. Less attendance; } \\
\text { 6. Practical, lab and ward visit is not } \\
\text { possible; } \\
\text { 7. Real medical learning is impossible. }\end{array}$ & $4(8 \%)$ & No response \\
\hline $\begin{array}{l}\text { 3. Have any prospect } \\
\text { of online education? }\end{array}$ & $15(29 \%)$ & $\begin{array}{l}\text { Nobody knows when exactly all the } \\
\text { educational institution will open. So, } \\
\text { online education is very crucial for } \\
\text { students. It will help students to redeem } \\
\text { their academic progress. } \\
\text { Psychological trauma can be removed } \\
\text { due to online education during } \\
\text { COVID-19 period. }\end{array}$ & $26(71 \%)$ & Find no prospect \\
\hline
\end{tabular}

Table 1: Presentation of data collected from the respondents.

\section{Results and Discussion}

The Major findings and results of this study are online education is helpful for students like it is better than no education. Theoretical classes and completion of courses are possible to conduct by maintaining social and physical distance but practical, ward visits, written exams, and face to face interaction of teachers and students are impossible. Therefore, real medical education is hampered and session jams appear. Besides, there are several crises and problems like internet problem, lack of ICT based devices, poor network, and lack of skills and facilities of online medical education found in this study.

Table 1 indicates represents the responses of respondents about three basic questions of online medical education during the COVID-19 pandemic. In response to the question of benefits of online medical education, only $20(39 \%)$ out of $51(100 \%)$ respondents gave their opinions that there are some benefits like online education, for instance, to stay at home it is possible to attend online class without classroom; through online system social and physical distance maintain is possible; theoretical classes and syllabus has completed; online medical education is keeping students busy as a result they are not affected by depression; online classes are always better than no classes at all because they got some basic ideas and guidelines about their courses. However, 31(61\%) respondents say online education is not beneficial for them and learning real medical education is not possible.

On the other hand, in response to the question of problems of online medical education, $92 \%$ of respondents 


\section{Epidemiology International Journal}

gave their opinions that they have suffered a lot to attend and complete their courses via the online education system. According to them, major problems are: to manage the schedule for all the courses is very tough as it uses by a specific online system like zoom or Google class so at a time very few teachers can engage in this system due to lack of strong network and internet speed. Similarly, interruption of the internet due to lack of and poor broadband internet most of the students could not stay connected and listen to the whole class even teachers also disconnected several times during class time. Most of the students are from rural areas of Bangladesh and they have no internet facilities and electronic devices (laptop, computer, and smartphone). Therefore, the attendance of students is less than in the offline classroom. Finally, some more important issues like a practical, lab test, written exam, and ward visit are not possible. Therefore, real medical learning is hampered which is a big threat for a nation like Bangladesh. In response to this question, $8 \%$ of students have no response.

The last question was the prospects of online medical education. In response to this question, only $29 \%$ of students think online medical education has some prospects but not beneficial for the long-term. They think online education has become a new normal. Nobody knows when exactly all the educational institutions will open. It will help students to advance their academic progress. Psychological trauma can be removed due to online education during the COVID-19 period. However, $71 \%$ of respondents think there are no prospects in online medical education as it is a very crucial and technical and practical knowledge based education.

Besides, several threats and problems may appear which have been mentioned by the Time Magazine reports. The report mentioned that more screen time is linked to poorer progress on key developmental measures such as communication skills, problem-solving, and social interactions among young generations. It is undeniable that the fewer soft-skills students have, the less they are likely to be hired by the employers of prestigious organizations, resulting in the failure in professional life [17]. Similarly, a study conducted by the National Centre for Biotechnology Information reveals that spending six hours or more a day watching TV or using computers is associated with a higher risk for depression [18]. Apart from that, scientific research suggests that excessive screen time results in obesity, blurred vision, chronic neck and back pain, coupled with a loss of cognitive ability. As the crisis prolongs the socio-economic impacts stemming from Covid-19 will have long-term consequences. The lifetime income and productivity would be severely constrained if the government does not step in with bolstered short-term and long-term public policies as follows [19].
First, when opening up the educational institution healthcare protocols should be strictly followed prescribed by WHO. Second, ensuring a return to medical for each student's existing stipend programs, exploring the options for 'education loans', communication campaigns, active engagement with families in distress, etc. should be prioritized [20]. Steps should be taken to reduce the digital divides across income groups as well as across regions. Last, but most importantly, the government must increase allocation in education. Bangladesh's expenditure in education, both as a percentage of Gross Domestic Product (GDP) and as a percentage of total tax revenue is one of the lowest in the world. In 2016, Bangladesh spent around 1.5 percent of its GDP on education.

\section{Conclusion}

The online classes for medical education during the COVID-19 pandemic situation are a positive and noble initiative within limitations. However, it also felt that such classes cannot be a replacement of classroom teaching for a long time as medical education is primarily based on practical, lab tests, patient's tests, professional and highly specialized. In this study, according to the observation of faculty and students' opinions live online classes for medical students can be concluded only for the interim emergency period and it is not fruitful for real medical education. Though some benefits were found several limitations were also found which hampered the attendance of students. According to one of the reports published in The Washington Post, prolonged sitting in front of computers or smartphones is dangerous and is associated with a significantly higher risk of heart disease, diabetes, obesity, cancer, and depression, as well as muscle and joint problems [21].

Similarly, Harvard Medical School researchers have shown that excessive use of computers or smart phones emitting blue lights can disrupt sleep patterns by suppressing the secretion of the hormone melatonin [17]. If the COVID-19 pandemic continues for long time the global education, health, economy, law and order, and smooth governance will be severely hampered. Therefore, people should maintain and follow health guidelines and all the government should take effective steps to buy or produce vaccine to prevent and protect people from COVID-19. Similarly, Harvard Medical School researchers have shown that excessive use of computers or smartphones emitting blue lights can disrupt sleep patterns by suppressing the secretion of the hormone melatonin [22]. If the COVID-19 pandemic continues for a long time the global education, health, economy, law and order, and smooth governance will be severely hampered. Therefore, people should maintain and follow health guidelines and the government should take effective steps to buy or produce a vaccine to prevent and protect people from 


\section{Epidemiology International Journal}

COVID-19.

\section{References}

1. Khanom M, Hoque A, Sharif PI, Sabuj MU, Hossain A, et al. (2020) How were the Online Classes in Undergraduate Medical Teaching during COVID Pandemic? Students' Views of a Non-Government Medical College in Bangladesh. Bangladesh Journal of Medical Education 11(2): 1-11.

2. (2020) Policy Brief: Education during COVID19 and beyond. United Nations.

3. Kainat A, Muhammad A (2020) Online learning amid the COVID- 19 pandemic: Students perspectives. Journal of Pedagogical Sociology and Psychology 2(1): 45-51.

4. Giorgi B, David K (2020) Transition to Online Education in Schools during a SARS-CoV-2 Coronavirus (COVID-19) Pandemic in Georgia. Pedagogical Research 5(4): 1-9.

5. Subramaniam NK, Kandasamy M (2011) The virtual classroom: A catalyst for institutional transformation. Australasian Journal of Educational Technology 27(8): 1388-1412.

6. Murphy MPA (2020) COVID-19 and emergency eLearning: Consequences of the securitization of higher education for post-pandemic pedagogy. Contemporary Security Policy 41(3): 492-505.

7. Bao W (2020) COVID-19 and online teaching in higher education: A case study of Peking University. Hum Behav \& Emerg Tech 2(2): 113-115.

8. Huang RH, Tlili DJ, Yang A, Yang JF, Wang HH (2020) Handbook on Facilitating Flexible Learning During Educational Disruption; The Chinese Experience in Maintaining Undisrupted Learning in COVID-19 Outbreak. Smart Learning Institute of Beijing Normal University.

9. Islam MT, Selim ASM (2006) Current Status and
Prospects for E-learning in the Promotion of Distance Education in Bangladesh. Turkish Online Journal of Distance Education 7(1): 1-9.

10. Triola MM, Friedman E, Cimino C, Geyer EM, Wiederhorn J, et al. (2010) Health information technology and the medical school curriculum. Am J Manag Care 16(12): 5456.

11. Thompson $P$ (2013) The digital natives as learners: technology use patterns and approaches to learning. Computer Education 65(7): 12-33.

12. Daniel J (2012) Making sense of MOOCs: musings in a maze of myth, paradox and possibility. Journal of Interactive Media in Education 2012(3): 18.

13. Cook DA, Levinson AJ, Garside S, Dupras DM, Erwin PJ, et al. (2008) Internet based learning in the health professions: a meta-analysis. JAMA 300(10): 1181-1196.

14. Bartley SJ, Golek JH (2004) Evaluating the cost effectiveness of online and face-to-face instruction. J Educ Technol Soc 7(4): 167-175.

15. Muilenburg LY, Berge ZL (2005) Student barriers to online learning: a factor analytic study. Distance Educ 26(1): 29-48.

16. Mayer RE (2002) Multimedia learning. Psychol Learn Motiv 41(1): 85-139.

17. (2020) OP-ED: How to make online education more effective. The Dhaka Tribune.

18. Ibid.

19. Uddin M (2020) Effects of the pandemic on the education sector in Bangladesh. The Financial Express 21: 17.

20. Ibid.

21. Ibid.

22. Ibid. 